American Journal of Applied Sciences 6 (4): 586-593, 2009

ISSN 1546-9239

(C) 2009 Science Publications

\title{
The Temperature Dependence Coefficients of Amorphous Silicon and Crystalline Photovoltaic Modules Using Malaysian Field Test Investigation
}

\author{
${ }^{1}$ Sulaiman Shaari, ${ }^{2}$ Kamaruzzaman Sopian, ${ }^{3}$ Nowshad Amin and ${ }^{1}$ Mohd Nizan Kassim \\ ${ }^{1}$ Faculty of Applied Sciences, University Teknologi MARA, 40450 Shah Alam, Malaysia \\ ${ }^{2}$ Solar Energy Research Institute, National University of Malaysia (UKM), 43600 Bangi, Malaysia \\ ${ }^{3}$ Deparment of Electrical Electronics and System Engineering, National University of Malaysia, Bangi, \\ Selangor 43600, Malaysia
}

\begin{abstract}
The temperature dependence coefficients of amorphous silicon and crystalline photovoltaic (PV) modules using Malaysian field data have been obtained using linear regression technique. This is achieved by studying three test stand-alone PV-battery systems using $62 \mathrm{Wp}$ a-Si, $225 \mathrm{Wp}$ multicrystalline and $225 \mathrm{Wp}$ mono-crystalline $\mathrm{PV}$ modules. These systems were designed to provide electricity for rural domestic loads at $200 \mathrm{~W}, 500 \mathrm{~W}$ and $530 \mathrm{~W}$ respectively. The systems were installed in the field with data monitored using data loggers. Upon analysis, the study found that the normalized power output per operating array temperature for the amorphous silicon modules, multicrystalline modules and mono-crystalline modules were: +0.037 per $^{\circ} \mathrm{C},+0.0225$ per ${ }^{\circ} \mathrm{C}$ and +0.0263 per ${ }^{\circ} \mathrm{C}$ respectively. In addition, at a solar irradiance value of $500 \mathrm{Wm}^{-2}$, the current, voltage, power and efficiency dependence coefficients on operating array temperatures obtained from linear regression were: $+37.0 \mathrm{~mA}$ per ${ }^{\circ} \mathrm{C},-31.8 \mathrm{mV}$ per ${ }^{\circ} \mathrm{C},-0.1036 \mathrm{~W}$ per ${ }^{\circ} \mathrm{C}$ and $-0.0214 \%$ per ${ }^{\circ} \mathrm{C}$, for the a-Si modules, $+22.5 \mathrm{~mA}$ per ${ }^{\circ} \mathrm{C},-39.4 \mathrm{mV}$ per ${ }^{\circ} \mathrm{C},-0.2525 \mathrm{~W}$ per ${ }^{\circ} \mathrm{C},-0.072 \%$ per ${ }^{\circ} \mathrm{C}$ for the multi-crystalline modules and $+26.3 \mathrm{~mA}$ per ${ }^{\circ} \mathrm{C},-32.6 \mathrm{mV}$ per ${ }^{\circ} \mathrm{C},-0.1742 \mathrm{~W}$ per ${ }^{\circ} \mathrm{C},-0.0523 \%$ per ${ }^{\circ} \mathrm{C}$ for the mono-crystalline modules. These findings have a direct impact on all systems design and sizing in similar climate regions. It is thus recommended that the design and sizing of PV systems in the hot and humid climate regions of the globe give due address to these findings.
\end{abstract}

Key words: Solar photovoltaics (PV), temperature dependence coefficients, field data

\section{INTRODUCTION}

The world photovoltaic (PV) cell and module technology production comprise mainly multicrystalline (multi-c), monocrystalline (mono-c) and amorphous silicon (a-Si). Amongst these, the use of a-Si PV modules has popularly been claimed to offer better performances than crystalline modules in the hotter climate regions of the world. Extensive research in PV applications and performances in the various regions of the globe have been undertaken covering both the a-Si and crystalline modules ${ }^{[1-4]}$. In addition, several works have been accomplished in obtaining the temperature dependence coefficients of these types of modules besides research into the a-Si material itself $^{[5-8]}$. Despite available data from the various parts of the world, quantified data from the hot and humid climate region such as the Southeast Asian region is very difficult to be found. The issue is becoming urgent as one of the countries in the region that has a wellplanned PV programme is Malaysia, via the United
Nations Development Programme (UNDP) co-funded PV project with the Government of Malaysia, which focuses on Building integrated Photovoltaics (BiPV) ${ }^{[11]}$. This impending programme involves the applications of $\mathrm{BiPV}$ in urban areas that will involve the various PV module technologies. Being in the hot and humid tropics, specific issues on the temperature coefficients of the PV modules would have a direct impact on the sizing and designing of the PV systems. However, to date, there exists very few works in this area in Malaysia $^{[10]}$. This becomes an irony since the region provides a very suitable area for the applications of PV technology, especially the a-Si technology due to its anticipated performance at the elevated temperatures of the region. In addition, the relatively large percentage of non-grid connected rural and remote inhabitants in the Southeast Asian region make PV technology application very promising. The cost issues of a-Si modules versus the crystalline modules exacerbate this irony. This paper presents a summary of the collected data on the performance of the a-Si and crystalline PV

Corresponding Author: Sulaiman Shaari, Faculty of Applied Sciences, University Teknologi MARA, 40450 Shah Alam, Malaysia 
modules in operating field conditions in Malaysia. These data were then analyzed using linear regression to obtain the temperature dependence coefficients for the a-Si and crystalline modules. The significance of these information serves as a guide for the suitable design and sizing of PV systems in similar regions of the globe.

\section{MATERIALS AND METHODS}

Systems design and sizing: In this study, three types of stand-alone PV systems were installed using the: Amorphous (a-Si) modules, multi-crystalline (multi-c) modules and mono-crystalline (mono-c) modules. Each of these systems has been designed to provide Alternating Current (AC) electricity to a small domestic load. Calculations for the systems sizing were done using hand calculations and confirmed using a dedicated sizing software called PVSYST 4.31@ ${ }^{[15]}$.

The PV modules used were USX11, BP275 and $\mathrm{BP} 275$, rated at $11 \mathrm{Wp}, 75 \mathrm{Wp}$ and $75 \mathrm{Wp}$ respectively. The operating voltage for each system was $12 \mathrm{~V} \mathrm{DC}$ and each system was coupled with a set of sealed solar batteries using the Valve Regulated Lead Acid (VRLA) batteries. A capacity of 100 Ah per battery was used for the a-Si system and a capacity of $125 \mathrm{Ah}$ per battery each was used for the crystalline systems. The inverters used were SELECTRONICS LD200 for each system with outputs of $200 \mathrm{~W} \mathrm{AC,} 240 \mathrm{~V} \mathrm{AC}$ and $50 \mathrm{~Hz}$. The $\mathrm{AC}$ loads used were three $9 \mathrm{~W}$ AC energy saving compact fluorescent lamp (CFL) for the a-Si system and a $35 \mathrm{~W}$ AC and $55 \mathrm{~W}$ AC low pressure sodium lamps (LPS) for the multi-c and mono-c systems respectively. These loads were powered via their individual inverters. The design and sizing parameters for each system is shown in Table 1 .

PV systems installation: All three PV systems were installed side-by-side in an open field with the modules facing due South and tilted at $15^{\circ}$ from the horizontal using metal frames with grounding. The basic schematic wiring diagram for each PV system is shown in Fig. 1.

Monitoring system: The monitoring system comprised of three sets of units: 1) an Environmental Monitoring Station (EMS) for acquiring data of the ambient, 2) Hall Effect (HE) sensors and 3) operating array temperature. Units 1 and 2 used a Campbell Scientific CR23X( ) data loggers ${ }^{[14]}$ whilst unit 3 used a Yokogawa CR130 data logger. References on monitoring were based on available published guidelines ${ }^{[15]}$ The EMS system measured: global irradiance on the horizontal and tilted planes at $15^{\circ}$, ambient temperature, relative humidity,
Table 1: Summary of the design and sizing parameters of the respective PV systems from the manufacturer's specifications. CFL-Compact Fluorescent Lamp, LPS-Low Pressure Sodium lamp

\begin{tabular}{lllll}
\hline Parameter & Units & $\begin{array}{l}\text { a-Si } \\
\text { system I }\end{array}$ & $\begin{array}{l}\text { Multi-c } \\
\text { system II }\end{array}$ & $\begin{array}{l}\text { Mono-c } \\
\text { system III }\end{array}$ \\
\hline Module model & - & USX11 & BP275 & BP275 \\
Total nominal power & Wp & 66 & 225 & 225 \\
Peak rating of module & Wp & 11 & 75 & 75 \\
Efficiency coefficient & $\%{ }^{\circ} C^{-1}$ & NA & NA & NA \\
Module configuration & - & $1 \times 6$ & $1 \times 3$ & $1 \times 3$ \\
Systems voltage & V DC & 12 & 12 & 12 \\
Battery model & - & Dryfit & Dryfit & Dryfit \\
Battery capacity & Ah & 100 & 125 & 125 \\
Battery configuration & - & $1 \times 2$ & $1 \times 2$ & $1 \times 2$ \\
Inverter model & - & LD200-12 & LD200-12 & LD200-12 \\
Inverter rating & W & 200 & 200 & 200 \\
Lamp model & - & CFL & LPS & LPS \\
Lamp rating power & W AC $^{\text {Aamp }}$ & 9 & 35 & 55 \\
Number of lamps & - & 3 & 1 & 1 \\
Daily load duration & $\mathrm{h}$ & 4 & 12 & 8 \\
Daily load demand & Whd $^{-1}$ & 200 & 500 & 530 \\
\hline
\end{tabular}

wind speed and direction. The Hall Effect sensors were used to measure: $\mathrm{DC}$ and $\mathrm{AC}$ currents, $\mathrm{DC}$ and $\mathrm{AC}$ voltages and the operating module temperatures were measured using thermocouples attached to the back of the modules. A summary of the complete monitoring systems used is shown in Table 2.

Monitoring of the systems commenced in 2003 and the complete setup of the installations with monitoring equipments is shown in Fig. 2.

Sample photographs of the systems are shown in the Plate 1 and 2.

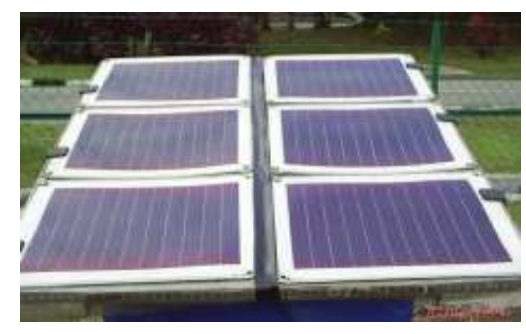

Plate 1: The a-Si modules used in System I.

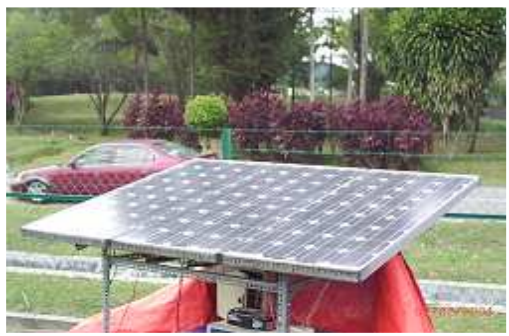

Plate 2: The multi and mono crystalline modules used in Systems II and III 


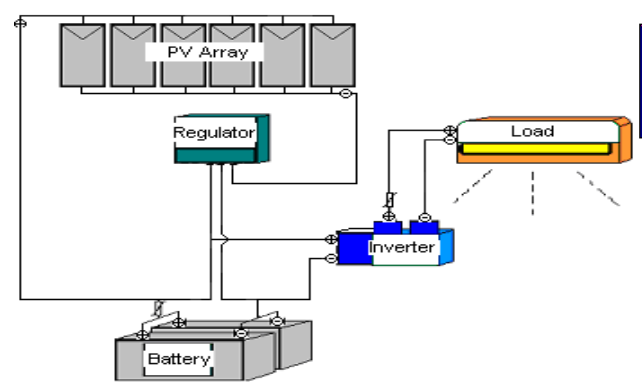

(a)

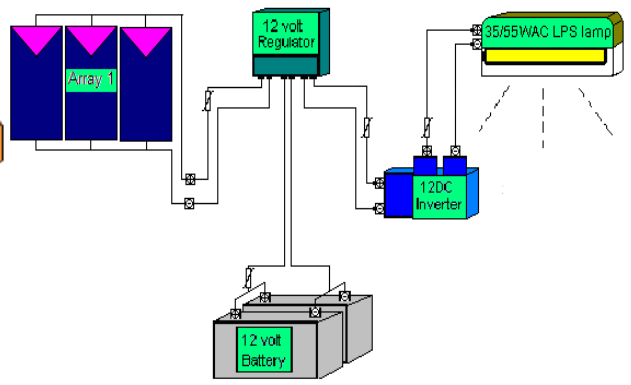

(b)

Fig. 1: Block diagram of the PV systems using: (a) a-Si modules; (b) Multi-c and Mono-c modules

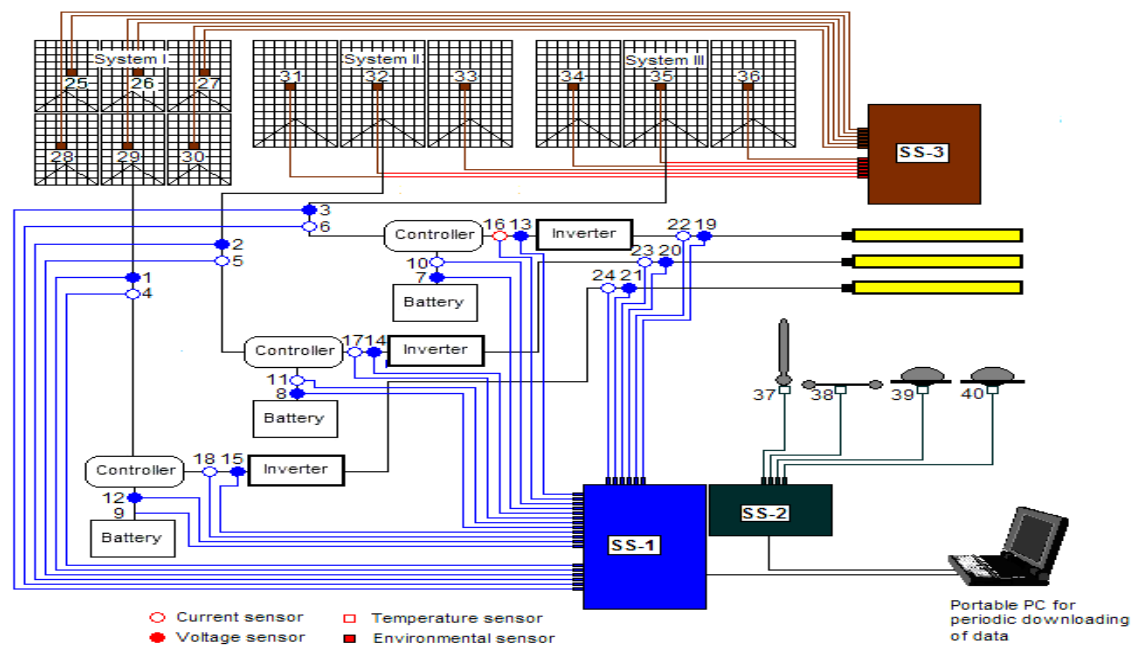

Fig. 2: Installation of the PV systems with monitoring equipment for: a-Si modules (System I); multi-c (System II) and mono-c (System III) modules

Table 2: Summary of the complete monitoring system.

\begin{tabular}{|c|c|c|}
\hline Parameter & No & Model \\
\hline Datalogger unit no 1 and no 2 & 1 & Campbell scientific $(\odot)$ \\
\hline Datalgger unit no 3 & 1 & Yokogawa DCR 130 \\
\hline $\begin{array}{l}\text { Global solar irradiance- } \\
\text { horizontal and tilted }\end{array}$ & 2 & Eppley \\
\hline Ambient temperature & 1 & CS500 RTD \\
\hline Wind speed and direction & 1 & 034B Met-One \\
\hline Current-DC and AC & $2+2$ & RS 286-377/RS 286-456 \\
\hline Voltage-DC and AC & $2+2$ & RS 286-361/RS 286-361 \\
\hline Module temperature & 6 & T type \\
\hline
\end{tabular}

Temperature dependence models: The empirical relationship between module temperature differential and solar irradiance is given as ${ }^{[16,17]}$ :

$$
\mathrm{T}_{\mathrm{m}}=\mathrm{T}_{\mathrm{a}}+\mathrm{kG}
$$

where:

$\mathrm{Tm}=$ Module temperature $\left({ }^{\circ} \mathrm{C}\right)$

$\mathrm{Ta}=$ Ambient temperature $\left({ }^{\circ} \mathrm{C}\right)$

$\mathrm{K}$ = Coefficient of relationship $\left({ }^{\circ} \mathrm{C} \mathrm{W}^{-1} \mathrm{~m}^{2}\right)$

$\mathrm{G}=$ Solar irradiance $\left(\mathrm{kWm}^{-2}\right)$
In addition, the current, voltage and power dependences on temperature are often reported as ${ }^{[20]}$ :

$$
\begin{aligned}
& \frac{\Delta \mathrm{I}}{\Delta \mathrm{T}}=+\mathrm{am} \mathrm{m}^{0} \mathrm{C}^{-1} \\
& \frac{\Delta \mathrm{V}}{\Delta \mathrm{T}}=-\mathrm{b} \mathrm{mV}^{0} \mathrm{C}^{-1} \\
& \frac{\Delta \mathrm{P}}{\Delta \mathrm{T}}=-\mathrm{c} \mathrm{W}{ }^{0} \mathrm{C}^{-1}
\end{aligned}
$$

where $\Delta \mathrm{I}, \Delta \mathrm{V}, \Delta \mathrm{P}$ and $\Delta \mathrm{T}$ are the increments in current $(\mathrm{mA})$, voltage $(\mathrm{V})$, power $(\mathrm{W})$ and operating module temperature $\left({ }^{\circ} \mathrm{C}\right)$ respectively, a, b and $\mathrm{c}$ are coefficients.

The set of Eq. 2 indicates that the current, voltage and power of the PV modules vary according to the operating module temperature. The current has a positive coefficient whilst the voltage and power have negative coefficients. In this study, these quantities are 
studied and analyzed to obtain quantified information with regards to performances based on temperature effects using specific Malaysian field data.

\section{RESULTS AND DISCUSSION}

Sample results: Sample graphical plots of the Malaysian field data of the solar irradiances, the ambient temperatures and operating module temperatures of the PV systems in this study are shown in Fig. 3.

From Fig. 3, it is apparent that the time basis plot shows that the pattern of power outputs from all three PV systems follow very closely with the solar irradiance which peaks at about 1200-1300 h. In addition, this power output does not seem to coincide with the trend of the ambient temperature, whose peaks occur at 1300 hours and 1600 hours respectively. As a relative comparison, the averaged hourly maximum temperatures of the ambient, a-Si, multi-c and mono-c arrays were $43.6^{\circ} \mathrm{C}, 58.4^{\circ} \mathrm{C}, 65.4^{\circ} \mathrm{C}$ and $51.6^{\circ} \mathrm{C}$ respectively while the hourly averaged maximum solar irradiance was about $983 \mathrm{Wm}^{-2}$.

Normalized power output versus operating array temperature: It would be very interesting to analyses the same data using a scatter plot of the normalized power output (that was calculated as the ratio of the generated power output to the peak rating of each of the PV systems) against the operating array temperatures. The results depict a very revealing scenario as shown in Fig. 4, 5 and 6.

From Fig. 4, the scatter plot for the a-Si PV System I shows that there is a linear relationship between the normalized power output with the operating array temperature. Using linear regression, this relationship can be expressed as follows:

$$
\mathrm{y}_{\mathrm{a}_{-} \mathrm{Si}}=0.037 \mathrm{x}-0.5921
$$

where $\mathrm{y}_{\mathrm{a}-\mathrm{Si}}$ is the normalized power output and $\mathrm{x}$ is the operating array temperature $\left({ }^{\circ} \mathrm{C}\right)$.

Of major significance is the nature of the equation itself; which is linear and that the gradient of Eq. 3, which has a value of $0.037{ }^{\circ} \mathrm{C}^{-1}$ that quantifies the relationship. This means that the normalized power output has a direct relationship with the operating array temperature.

From Fig. 5, the scatter plot for the multi-c PV System II shows that there is a linear relationship between the normalized power output with the operating array temperature. Using linear regression, this relationship can be expressed as follows.

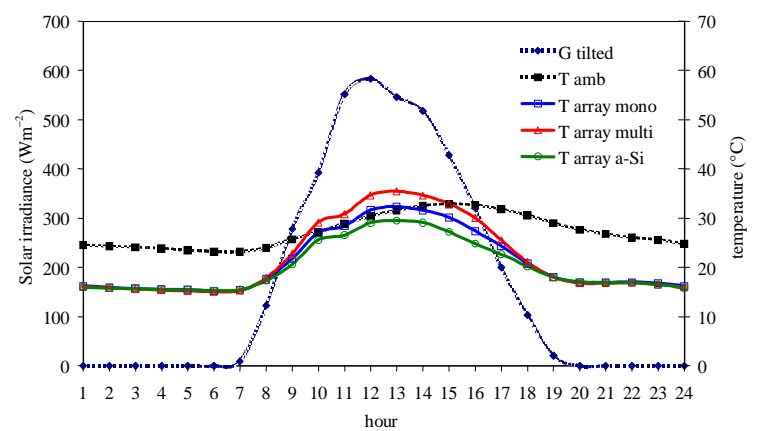

Fig. 3: Graph of hourly averaged solar irradiance, the ambient and operating module temperatures for all the PV systems from October 2003 to March 2004. G tilted is the global solar irradiance on the collector plane; Tamb is the ambient temperature

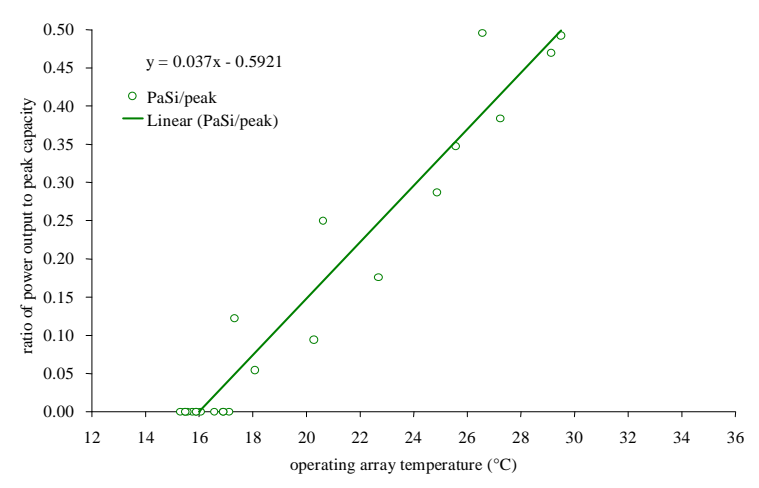

Fig. 4: Scatter plot of hourly averaged normalized power output versus operating array temperature for the a-Si PV system from October 2003 to March 2004

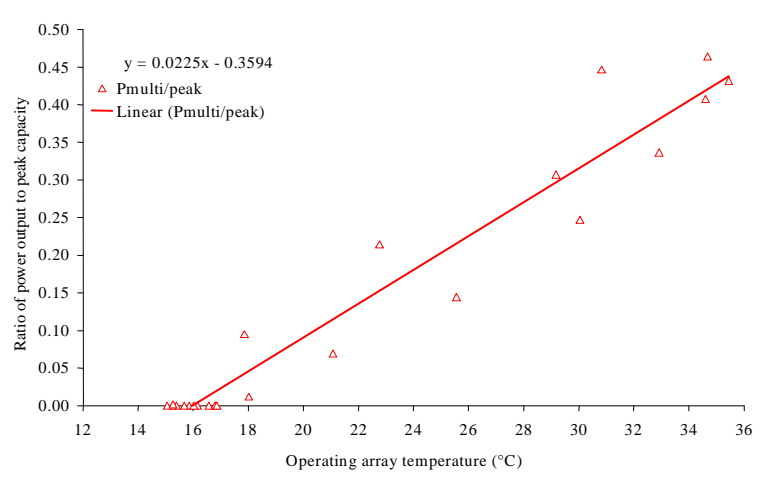

Fig. 5: Scatter plot of hourly averaged normalized power output versus operating array temperature for the multi-c PV system from October 2003 to March 2004 


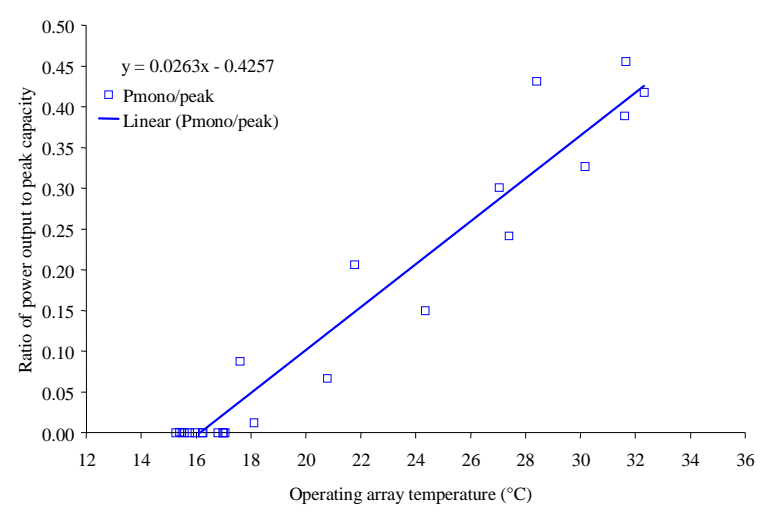

Fig. 6: Scatter plot of hourly averaged normalized power output versus operating array temperature for the mono-c PV system from October 2003 to March 2004

$$
\mathrm{y}_{\text {multi_c }}=0.0225 \mathrm{x}-0.3594
$$

where $\mathrm{y}_{\text {multicc }}$ is the normalized power output and $\mathrm{x}$ is the operating array temperature $\left({ }^{\circ} \mathrm{C}\right)$.

Of major significance is the nature of the equation; which is linear and that the gradient of Eq. 4, which has a value of $0.0225^{\circ} \mathrm{C}^{-1}$ that quantifies the relationship. This also means that the normalized power output also has a direct relationship with the operational array temperature.

From Fig. 6, the scatter plot for the mono-c PV System II shows that there is a linear relationship between the normalized power output with the operating array temperature. Using linear regression, this relationship can be expressed as follows.

$$
\mathrm{y}_{\text {mono_c }}=0.026 \mathrm{x}-0.4257
$$

where $\mathrm{y}_{\text {mono_c }}$ is the normalized power output and $\mathrm{x}$ is the operating array temperature $\left({ }^{\circ} \mathrm{C}\right)$.

Of major significance is the nature of the equation; which is linear and that the gradient of Eq. 5, which has a value of $0.0263^{\circ} \mathrm{C}^{-1}$ that quantifies the relationship. This also means that the normalized power output also has a direct relationship with the operating array temperature.

As a comparison, the findings above are shown in the Table 3.

From the values shown in Table 3 , there is an apparent increase of the generated normalized power output per degree rise in operating array temperature. The highest increase is for System I (a-Si), followed by System III (mono-c) and lastly System II (multi-c), with gradients of $0.0370,0.0263$ and $0.0225^{\circ} \mathrm{C}^{-1}$

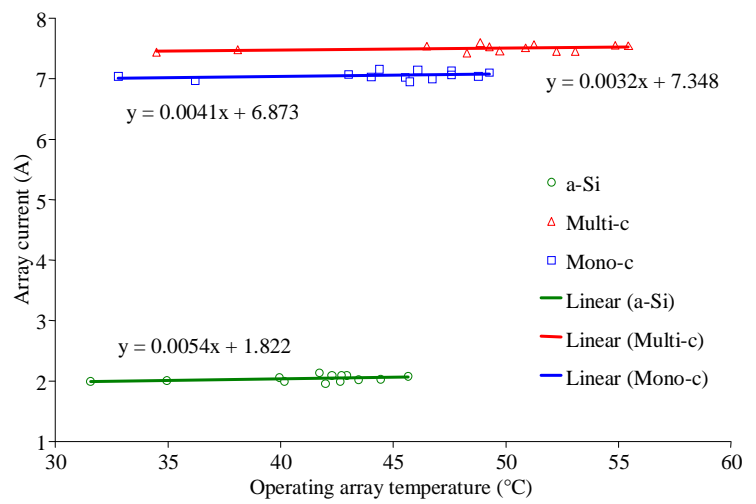

Fig. 7: Scatter plot of hourly averaged array currents versus hourly averaged operating array temperatures for all the PV systems from October 2003 to March 2004

Table 3: Summary of linear models from the Malaysian field data.

\begin{tabular}{lll}
\hline PV installation & Linear model & Gradient $\left({ }^{\circ} \mathrm{C}^{-1}\right)$ \\
\hline System I (a-Si) & $\mathrm{y}=0.0370 \mathrm{x}-0.5921$ & +0.0370 \\
System II (multi-c) & $\mathrm{y}=0.0225 \mathrm{x}-0.3594$ & +0.0225 \\
System III (mono-c) & $\mathrm{y}=0.0263 \mathrm{x}-0.4257$ & +0.0263 \\
\hline
\end{tabular}

Table 4: Summary of linear models for array current versus operating array temperature.

\begin{tabular}{lll}
\hline PV installation & Linear model & Gradient $\left(\mathrm{mA}^{\circ} \mathrm{C}^{-1}\right)$ \\
\hline System I (a-Si) & $\mathrm{y}=0.0370 \mathrm{x}-0.5921$ & +37.0 \\
System II (multi-c) & $\mathrm{y}=0.0225 \mathrm{x}-0.3594$ & +22.5 \\
System III (mono-c) & $\mathrm{y}=0.0263 \mathrm{x}-0.4257$ & +26.3 \\
\hline
\end{tabular}

respectively. The percentage difference between the highest and lowest values is about $49 \%$, which is quite significant. Thus, this is one set of quantified indication that the a-Si modules perform best in a hot and humid region, followed by the mono-c modules and lastly by the multi-c modules.

Array current versus operating array temperature: In this section, an analysis of the generated current from the PV systems is done with regards to their temperature dependences. This is done using scatter plots and regression analysis. The results are depicted in Fig. 7, which shows scatter plots of the hourly averaged array currents versus the hourly averaged operating array temperatures for all the PV systems taken at an hourly averaged solar irradiance of 500 $\mathrm{Wm}^{-2} \pm 2.5 \%$.

From Fig. 7, the scatter plot shows that there is a linear relationship between the hourly averaged array currents and the hourly averaged operating array temperatures for all the three PV systems. Using linear regression, these relationships are shown in Table 4. 
From the values shown in Table 4, there is an apparent increase of the generated array current per degree rise in operating array temperature. The highest increase is for System I (a-Si), followed by System II (mono-c) and lastly System II (multi-c), with gradients of $37.0 \mathrm{~mA}^{\circ} \mathrm{C}^{-1}, 26.3 \mathrm{~mA}^{\circ} \mathrm{C}^{-1}$ and $22.5 \mathrm{~mA}^{\circ} \mathrm{C}^{-1}$ respectively. The percentage difference between the highest and lowest values is also about $49 \%$, which is again quite significant. Thus, this is another quantified version that the a-Si modules perform best in a hot and humid region, followed by the mono-c modules and lastly by the multi-c modules.

Array voltage versus operating array temperature: In this section, an analysis of the generated voltage from the PV systems is done with regards to their temperature dependences. This is done using scatter plots and regression analysis. The results are depicted in Fig. 8, which shows scatter plots of the hourly averaged array voltages versus the hourly averaged operating array temperatures for all the PV systems taken at an averaged hourly solar irradiance of 500 $\mathrm{Wm}^{-2} \pm 2.5 \%$.

From Fig. 8, the scatter plot shows that there is a linear relationship between the hourly averaged array voltages and the hourly averaged operating array temperatures for all the three PV systems. Using linear regression, these relationships are shown in Table 5 .

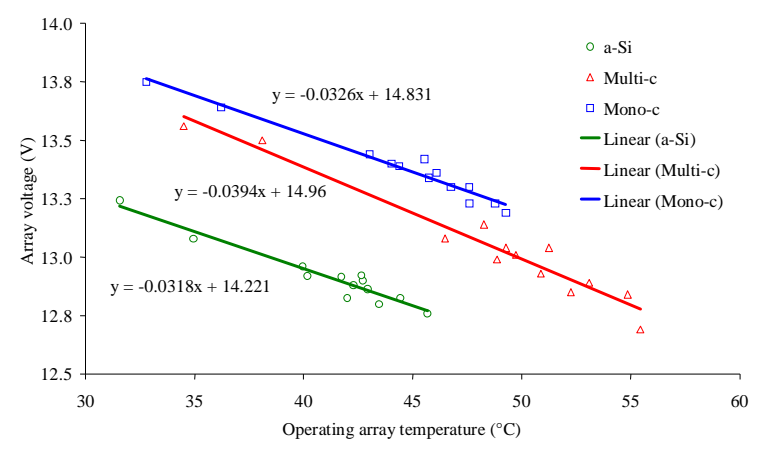

Fig. 8: Scatter plot of hourly averaged array voltages versus hourly averaged operating array temperatures for all the PV systems from October 2003 to March 2004

Table 5: Summary of linear models for array voltage versus operating array temperature.

\begin{tabular}{lll}
\hline PV installation & Linear model & Gradient $\left(\mathrm{mV}^{\circ} \mathrm{C}^{-1}\right)$ \\
\hline System I (a-Si) & $\mathrm{y}=-0.0318 \mathrm{x}+14.221$ & -31.8 \\
System II (multi-c) & $\mathrm{y}=-0.0394 \mathrm{x}+14.960$ & -39.4 \\
System III (mono-c) & $\mathrm{y}=-0.0326 \mathrm{x}+14.831$ & -32.6 \\
\hline
\end{tabular}

From the values shown in Table 5, there is an apparent deration of the generated array voltage per degree rise in operating array temperature. However, the smallest deration rate is for System I (a-Si), followed by System III (mono-c) and lastly System II (multi-c), with gradients of $-31.8 \mathrm{mV}^{\circ} \mathrm{C}^{-1},-32.6$ $\mathrm{mV}^{\circ} \mathrm{C}^{-1}$ and $-39.4 \mathrm{mV}^{\circ} \mathrm{C}^{-1}$ respectively. The percentage difference between the highest and lowest values is also about $21 \%$, which is again quite significant. This analysis quantifies that the a-Si modules again, perform best in a hot and humid region, followed by the mono-c modules and lastly by the multi-c modules.

Array power output versus operating array temperature: In this section, an analysis of the generated array power output from the PV systems is done with regards to their temperature dependences. This is done using scatter plots and regression analysis. The results are depicted in Fig. 9, which shows scatter plots of the hourly averaged array power output versus the hourly averaged operating array temperatures for all the PV systems taken at an averaged hourly solar irradiance of $500 \mathrm{Wm}^{-2} \pm 2.5 \%$.

From Fig. 9, the scatter plot shows that there is a linear relationship between the hourly averaged array power output and the hourly averaged operating array temperatures for all the three PV systems. Using linear regression, these relationships are shown in Table 6.

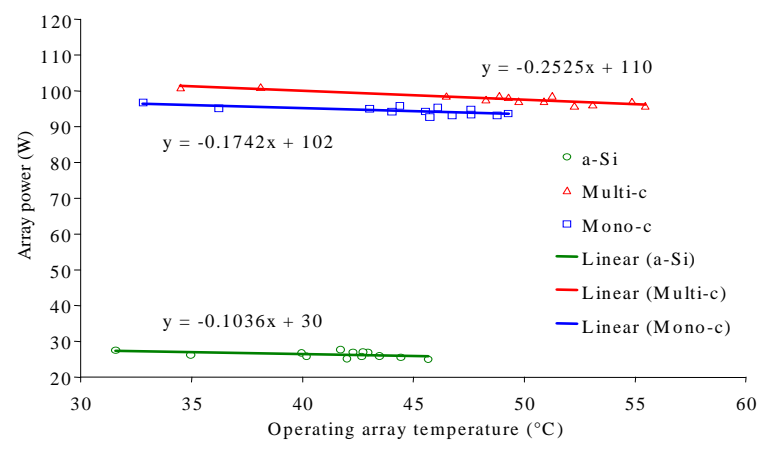

Fig. 9: Scatter plot of hourly averaged array power output versus hourly averaged operating array temperatures for all the PV systems from October 2003 to March 2004

Table 6: Summary of linear models for array power output versus operating array temperature.

\begin{tabular}{lll}
\hline PV installation & Linear model & Gradient $\left(\mathrm{W}^{\circ} \mathrm{C}^{-1}\right)$ \\
\hline System I (a-Si) & $\mathrm{y}=-0.1036 \mathrm{x}+30$ & -0.1036 \\
System II (multi-c) & $\mathrm{y}=-0.2525+110$ & -0.2525 \\
System III (mono-c) & $\mathrm{y}=-0.1742+102$ & -0.1742 \\
\hline
\end{tabular}


From the values shown in Table 6, again there is an apparent deration of the generated array power output per degree rise in operating array temperature. However, the smallest deration rate is for System I (a$\mathrm{Si}$ ), followed by System III (mono-c) and lastly System II (multi-c), with gradients of $-0.1036 \mathrm{~W}^{\circ} \mathrm{C}^{-1},-0.2525$ $\mathrm{W}^{\circ} \mathrm{C}^{-1}$ and $-0.1742 \mathrm{~W}^{\circ} \mathrm{C}^{-1}$ respectively. The percentage difference between the highest and lowest values is also about $83 \%$, which is very significant. This analysis quantifies that the a-Si modules again, perform best in a hot and humid region, followed by the mono-c modules and lastly by the multi-c modules.

Array conversion efficiency versus operating array temperature: In this section, an analysis of the array conversion efficiency from the PV systems is done with regards to their temperature dependences. This is done using scatter plots and regression analysis. The results are depicted in Fig. 10, which shows scatter plots of the hourly averaged array conversion efficiency versus the hourly averaged operating array temperatures for all the PV systems taken at an averaged hourly solar irradiance of about $500 \mathrm{Wm}^{-2} \pm 2.5 \%$.

From Fig. 10, the scatter plot shows that there is a linear relationship between the hourly averaged array conversion efficiency and the hourly averaged operating array temperatures for all the three PV systems. Using linear regression, these relationships are shown in Table 7.

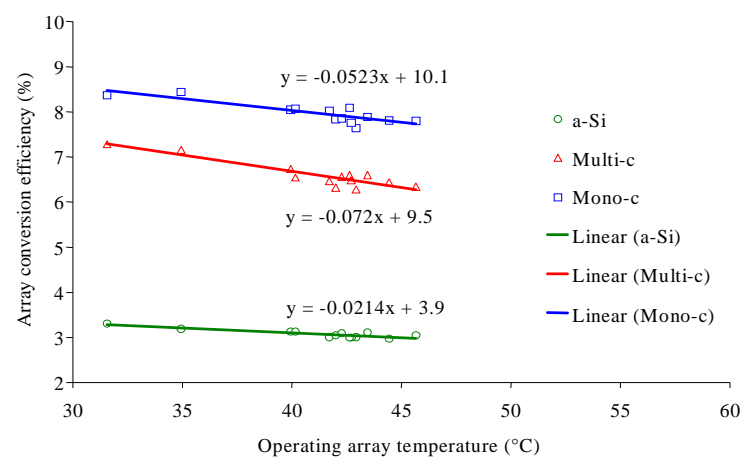

Fig. 10: Scatter plot of hourly averaged array conversion efficiency versus hourly averaged operating array temperatures for all the PV systems from October 2003 to March 2004

Table 7: Summary of linear models for array conversion efficiency versus operating array temperature.

\begin{tabular}{lll}
\hline PV installation & Linear model & Gradient $\left(\%{ }^{\circ} \mathrm{C}^{-1}\right)$ \\
\hline System I (a-Si) & $\mathrm{y}=-0.0214 \mathrm{x}+3.9$ & -0.0214 \\
System II (multi-c) & $\mathrm{y}=-0.0720 \mathrm{x}+9.5$ & -0.0720 \\
System III (mono-c) & $\mathrm{y}=-0.0523 \mathrm{x}+10.1$ & -0.0523 \\
\hline
\end{tabular}

From the values shown in Table 7 , there is an apparent deration of the array conversion efficiency per degree rise in operating array temperature. However, the smallest deration rate is for System I (a-Si), followed by System III (mono-c) and lastly System II (multi-c), with gradients of $-0.0214 \%{ }^{\circ} \mathrm{C}^{-1},-0.0523 \%$ ${ }^{\circ} \mathrm{C}^{-1}$ and $-0.0720 \%{ }^{\circ} \mathrm{C}^{-1}$ respectively. The percentage difference between the highest and lowest values is also about $54 \%$, which is very significant. This analysis quantifies that the a-Si modules again, perform best in a hot and humid region, followed by the mono-c modules and lastly by the multi-c modules.

\section{CONCLUSION}

The temperature dependence coefficients of the a$\mathrm{Si}$, mono-c and multi-c modules have been investigated using three stand-alone PV-battery systems and tested under Malaysian field conditions. Data of their operating module temperatures have been compiled and analyzed using linear regression to determine their respective temperature dependence coefficients. A summary of the findings is shown in Table 8 .

In essence, the quantified sets of values using the Malaysian field data as shown in Table 8 show that the a-Si modules perform significantly best in the hot and humid climate, showing the highest normalized power outputs and current coefficients, whilst showing the lowest deration coefficients in voltage, power and conversion efficiency. This trend is followed consistently by the mono-c modules and lastly by the multi-c modules. In summary, these findings have bearing and give significant impact on the design and sizing of PV systems for use in equatorial and tropical climate regions of the world. It is also recommended that more long term field data be monitored and analyzed to obtain a more comprehensive and conclusive set of values for the proper design and sizing of PV systems in the hot and humid climate regions of the globe.

Table 8: Summary of findings from the Malaysian field data

\begin{tabular}{lllll}
\hline Parameter & Unit & $\begin{array}{l}\text { System I } \\
(\mathrm{a}-\mathrm{Si})\end{array}$ & $\begin{array}{l}\text { System II } \\
\text { (Multi-c) }\end{array}$ & $\begin{array}{l}\text { System III } \\
\text { (Mono-c) }\end{array}$ \\
\hline $\begin{array}{l}\text { Normalized power output } \\
{ }^{\circ} \mathrm{C}^{-1}\end{array}$ & +0.0370 & +0.0225 & +0.0263 \\
Current coefficient & $\mathrm{mA}^{\circ} \mathrm{C}^{-1}$ & +37.0 & +22.5 & +26.3 \\
Voltage coefficient & $\mathrm{mA}^{\circ} \mathrm{C}^{-1}$ & -31.8 & -39.4 & -32.6 \\
$\begin{array}{l}\text { Power coefficient } \\
\text { Conversion efficiency }\end{array}$ & $\mathrm{W}^{\circ} \mathrm{C}^{-1}$ & -0.1036 & -0.2525 & -0.1742 \\
coefficient & $\%{ }^{\circ} \mathrm{C}^{-1}$ & -0.0214 & -0.0720 & -0.0523 \\
\hline
\end{tabular}

\section{ACKNOWLEDGEMENT}

The authors wish to express deep gratitude to the University Teknologi MARA (UiTM) generally and 
specifically to the Institute of Research, Development and Consultancy (IRDC) for the full funding and giving all the necessary help for this project, the Faculty of Applied Sciences, The Faculty of Electrical Engineering and the CADEM Centre, for all the help and support. Gratitude is also expressed to the Innovation Centre and the Maintenance Division for providing the much needed laboratory space and field site.

\section{REFERENCES}

1. Ruther, R. and M.M. Dacoregio, 2000. Performance assessment of a $2 \mathrm{kWp}$ gridconnected, building-integrated, amorphous silicon photovoltaic installation in Brazil. Progress Photovoltaics Res. Applic., 8: 257-266. http://www3.interscience.wiley.com/journal/71006 498/abstract?CRETRY $=1 \&$ SRETRY $=0$.

2. Zilles, R., E. Lorenzo and P. Serpa, 2000. From candles to PV electricity: A four-year experience at Iguape-Cananeia, Brazil. Progress in Photovoltaics Res. Applic., 8: 412-434. http://cat.inist.fr/?aModele $=$ afficheN\&cpsidt=1486 967.

3. Singh, O.P. et al., 1997. Performance of amorphous silicon solar cell module and solar lantern. J. Renewable Energy, 11: 421-426. http://cat.inist.fr/?aModele $=$ afficheN\&cpsidt $=2719$ 395.

4. Costa, H.S., P.H. Ragot and D. Desmettre, 1992. Evaluation of amorphous silicon module outdoor performances. J. Solar Energy Mat. Solar Cells, 27: $\quad$ 59-68. http://cat.inist.fr/?aModele $=$ afficheN\&cpsidt $=4594$ 026.

5. Lechner, P. and H. Schade, 2002. Photovoltaic thin-film technology based on hydrogenated amorphous silicon. Progress Photovoltaics Res. Applic., 10: 85-97. http://www3.interscience.wiley.com/journal/90010 570/abstract.

6. Guha, S., J. Yang and A. Banerjee, 2000. Amorphous silicon alloy photovoltaic researchpresent and future. Progress Photovoltaics Res. Applic., 8 : 141-150. http://www3.interscience.wiley.com/journal/70001 633/abstract?CRETRY $=1 \&$ SRETRY $=0$.
7. Keevers, M.J., 2000. Development of a fabrication process for parallel multijunction thin film silicon solar cells on wafer substrates. Progress Photovoltaics Res. Applic., 9: 579-589. http://cat.inist.fr/?aModele $=$ afficheN\&cpsidt $=8437$ 30 .

8. Smith, Z.E. and S. Wagner, 1985. A carrier lifetime model for the optical degradation of amorphous silicon solar cells. J. Solar Energy Mat. Solar Cells, 13: 90-89.

9. Haris, A.H., S. Shaari and K. Sopian, 2005. Building integrated photovoltaics in Malaysia: Systems, applications and the way forward. Proceeding of the National Seminar on Energy in Buildings, May 10-11, Malaysian Institute of Energy, Malaysia, pp: 150-156.

10. Kassim M.N. and S. Shaari, 2003. An Analysis of the Technical Performances of Three Sets of StandAlone a-Si Based Solar Photovoltaic Systems. In: P. of Advances in Malaysian Energy Research Sopian, Zain-Ahmed, Abd Rahman and Othman, (Eds.). Pub: Malaysian Institute of Energy, Bangi, pp: 253-262. ISBN: 983-40024-4-0.

11. Sopian, K., H. Zainuddin, B. Yatim and M.Y. Othman, 2001. Performance analysis of a gridconnected photovoltaic system for residential application. J. Ind. Technol., 10: 47-58.

12. Mermoud, A., 2008. http://www.unige.ch/cuepe/ pvsyst/pvsyst/projectdesign.php

13. Campbell Scientific, 2008. http://www.campbellsci.co.uk/

14. Treble, F.C., 1991. Generating Electricity From the Sun. 1st Edn., Pergamon Press, Oxford, UK., pp: 304. ISBN-10: 0080409369.

15. Overstraeten, R.J.V. and R.P. Mertens, 1986. Physics, Technology and use of Photovoltaics. Adam Hilger Ltd, Briston, UK., ISBN: 0-85274487-0

16. Duffie, J.A. and W.A. Beckman, 1991. Design of photovoltaic systems. Chapter in Solar Engineering of Thermal Processes, 2nd Edn., John Wiley and Sons Inc., Singapore.

17. Markvart, T., 2000. Solar Electricity. John Wiley and Sons, pp: 280. ISBN: 0471988529. 